\title{
SEBAHODNOTENIE A HODNOTOVÉ PREFERENCIE ŠTUDENTOV STREDNÝCH ŠKÔL
}

\author{
Katarína Baňasová1, Jaroslava Virgalová ${ }^{2}$ \\ 1Ústav aplikovanej psychológie FSVaZ UKF Nitra \\ ${ }^{2}$ Katedra psychologických vied FSVaZ UKF Nitra \\ kbanasova@ukf.sk
}

\begin{abstract}
Abstrakt: Hlavným ciel'om predkladanej štúdie bolo analyzovat' vájomný vzt’ah hodnôt a sebahodnotenia u stredoškolských študentov. Sekundárnym ciel'om bolo tiež overit' zistené výsledky komparačnou analýzou. Výskumnú vzorku tvorilo 108 študentov, 64 dievčat a 44 chlapcov, vo veku od 15 do 20 rokov. Na meranie hodnotových typov sme použili Schwartzovu škálu PVQ -RR. Sebahodnotenie sme zist'ovali pomocou Rosenbergovej škály sebahodnotenia. Výsledky nášho výskumu poukázali na štatisticky slabé pozitívne významné vzt'ahy medzi sebahodnotením a hodnotami sebaurčenie - myslenie, moc - dominancia, pokora, univerzalizmus príroda a univerzalizmus - záujem. Pri hodnotách hedonizmus, konformita interpersonálna, moc - materiálna a benevolencia - starostlivost' sme zistili štatisticky významné slabé negatívne vzt’ahy so sebahodnotením. Rozdiely medzi študentmi s nižšou a vyššou úrovňou sebahonotenia sa zistili v preferovaných hodnotách sebaurčenie-myslenie a moc-dominancia, zároveň by tieto hodnoty mohli bližšie objasňovat’ teóriu sebahodnotenia.

Kl'účové slová: sebahodnotenie, Schwartzova teória hodnôt, stredoškolskí študenti
\end{abstract}

\section{1 ÚVOD}

Počas adolescencie dochádza $\mathrm{k}$ odpútavaniu sa od primárnych vzt’ahových osôb (najčastejšie rodičov). Adolescenti tak vo vel'kej miere finalizujú dôležitú vývinovú úlohu - formovanie selfkonceptu, ktorého súčast'ou je aj sebaobraz, sebahodnota a vlastná identita (Kusý, 2017). Sebahodnotenie teda $v$ tomto období zohráva pre mladého človeka vel’mi dôležitú úlohu (Minev, Petrova, Mineva, Petkova, \& Strebkova, 2018).

Obdobie adolescencie je taktiež citlivým pre vytváranie si vzt’ahu k hodnotám. Rôzne štúdie (Lönnqvist a kol., 2009; Feather, 1998; Deniz, Dilmaç, \& Hamarta, 2016) ukázali prepojenie medzi sledovanými konceptami. Naším predpokladom je, že preferencia určitých typov hodnôt mladého človeka vypovedá nielen o jeho charaktere, ale taktiež aj o sebahodnotení.

Hlavným ciel'om predkladanej štúdie je analyzovat' vzt'ah hodnôt a sebahodnotenia u stredoškolských študentov. Sekundárnym ciel'om je overit' zistené výsledky komparačnou analýzou a porovnat' preferenciu hodnôt adolescentov s vyššou a nižšou úrovňou sebahodnotenia. V našom prípade sme sa zamerali na zmodernizovanú Schwartzovu teóriu základných l'udských hodnôt (2012), ktorá podrobne definuje 19 kroskultúrne platných hodnôt, a ktorú si nižšie predstavíme.

\subsection{Sebahodnotenie adolescentov}

Pojem sebahodnotenie (self esteem) po prvýkrát definoval americký psychológ Wiliam James vo svojej knihe „Principles of Psychology“, ktorá je mnohými odborníkmi považovaná za prvú americkú učebnicu psychológie. James sebahodnotenie definoval ako určitý sebaobraz, vd’aka 
ktorému oceňujeme alebo neoceňujeme to čím sme, čo robíme a aké výsledky dosahujeme (James, 1890). Úroveň sebahodnotenia na začiatku dospievania u väčšiny mladých l'udí prudko klesá a až okolo 15-16 roku začína znova stúpat'. Podl'a Vágnerovej (2000) sú výkyvy v sebahodnotení a emočná instabilita pre toto obdobie charakteristické.

V tomto veku má jednotlivec tendenciu posudzovat' sa predovšetkým podl'a reakcií druhých l'udí. Kritický pohl'ad na seba samého je na jednej strane nevyhnutnou podmienkou ujasnenia si vlastných osobnostných charakteristík, no na strane druhej je príčinou rôznych osobnostných kríz a dôvodom neustáleho utvrdzovania sa o svojej hodnote. (Langmeier \& Krejčířová, 2006).

Ak mladý človek hodnotí svoju identitu pozitívne, je viac než dost' pravdepodobné, že bude takýto človek úspešnejší v sociálnych vzt'ahoch a interakciách, komunikácii, bude sa správat' úprimne a nezávisle. Naopak adolescenti s nízkym sebahodnotením často čelia mnohým rizikám, ktoré súvisia s vytváraním negatívnejších vzt'ahov a zažívaním negatívnych emócii. V našej štúdii budeme skúmat' globálne sebahodnotenie, ktoré predstavuje vzt’ah, ktorý má človek k sebe samému (Brown, Dutton, \& Cook, 2001). V tomto ohl'ade sa sebahodnotenie považuje za výrazný potenciál v živote adolescentov (Çakar \& Karatas, 2017), ktorý vnímame úzko prepojený s hodntovou štruktúrou mladých l’udí, o ktorej sa zmienime v nasledujúcej kapitole.

\subsection{Schwartzova teória základných l'udských hodnôt}

V psychológii vnímame hodnoty ako naučené konštrukcie, ktoré si jednotlivec osvojuje od svojich rodičov, učitel'ov, rovesníkov a spoločnosti, a ktoré ovplyvňujú to, ako človek koná a stanovuje si vlastné ciele. Pre človeka je teda hodnotou všetko to, čo vedie k uspokojovaniu jeho potrieb a čo prispieva k jeho psychickej pohode (Fontana, 2003). Hodnoty môžu slúžit’ aj ako motivátory alebo naopak bariéry v procese dosahovania ciel’ov (Romanová, Sollár, \& Turzáková, 2016).

Jednotlivé motivačné typy hodnôt v Schwartzovej teórii (2012) sa zoskupujú do štyroch vyšších celkov, ktoré vyjadrujú protikladné póly dvoch dimenzií. Prvá dimenzia znázorňuje vzt'ah medzi „otvorenost'ou voči zmene“ a „konzervativizmom“. Protikladné póly druhej dimenzie sú „sebazdôrazňovanie“ a „sebatranscendencia“ (Davidov, Schmidt, \& Schwartz, 2008). Z hl'adiska vzt’ahov, hodnoty, ktoré sú v rámci kruhového modelu vedl'a seba, medzi sebou korelujú kladne a protil'ahlé hodnoty korelujú záporne. Čím bližšie sú hodnotové typy v modeli, tým viac sa zhodujú aj ich motivačné ciele (Schusterová, 2008). Pre lepšiu názornost' uvádzame kruhový model hodnôt (Obr. 1).

V súčasnosti sa stretávame s novou teóriou, ktorú rozpracoval Schwartz (2012), v ktorej je pôvodných desat' hodnôt rozšírených na devätnást'. Každá z nich opisuje základný motivačný ciel': (1) Samostatnost’ myslenia - sloboda vytvárania vlastných myšlienok; (2) Samostatnost' konania sloboda určovania vlastného správania; (3) Stimulácia - vzrušenie, zmena; (4) Pôžitkárstvo potešenie, zmyslové uspokojenie; (5) Úspech - úspech podl'a spoločenských noriem, (6) Moc dominancia - moc nad ostatnými l'ud'mi; (7) Moc - materiálna - moc prostredníctvom kontroly materiálnych a sociálnych zdrojov; (8) Prestíž - udržanie si svojho imidžu a vyhýbanie sa poníženiu; (9) Bezpečnost' - osobná bezpečnost' v bezprostrednom okolí; (10) Bezpečnost' spoločenská - bezpečnost’ a stabilita v širšej spoločnosti; (11) Tradície - zachovávanie kultúrnych, rodinných a náboženských tradícií, (12) Konformita - interpersonálna vyhýbanie sa rozrušeniu a poškodeniu druhých; (13) Konformita v pravidlách - zachovávanie pravidiel, zákonov a povinností; (14) Pokora - prijatie toho, čo je k dispozícii bez nárokov na niečo viac; (15) Univerzalizmus príroda - zachovanie prírodného prostredia; (16) Univerzalizmus - obavy - potreba rovnosti, spravodlivosti a ochrany l'udí; (17) Univerzalizmus - tolerancia akceptácia a pochopenie pre odlišných l'udí; (18) Benevolencia - spol’ahlivost' - byt' spol'ahlivým členom v skupine; (19) Benevolencia - starostlivost' - starostlivost' o potreby členov skupiny (Obr.1). 
V rámci kruhového modelu prvý vonkajší kruh je rozdelený na dve polovice, z toho jednu tvoria hodnoty zamerané na rast bez úzkosti a druhú polovicu tvoria hodnoty vyhýbajúce sa úzkosti. V druhom kruhu sú hodnoty rozdelené podl’a toho, či sú zamerané na seba, a tie, ktoré sú zamerané na druhých (Schwartz, 2012; Obr.1).

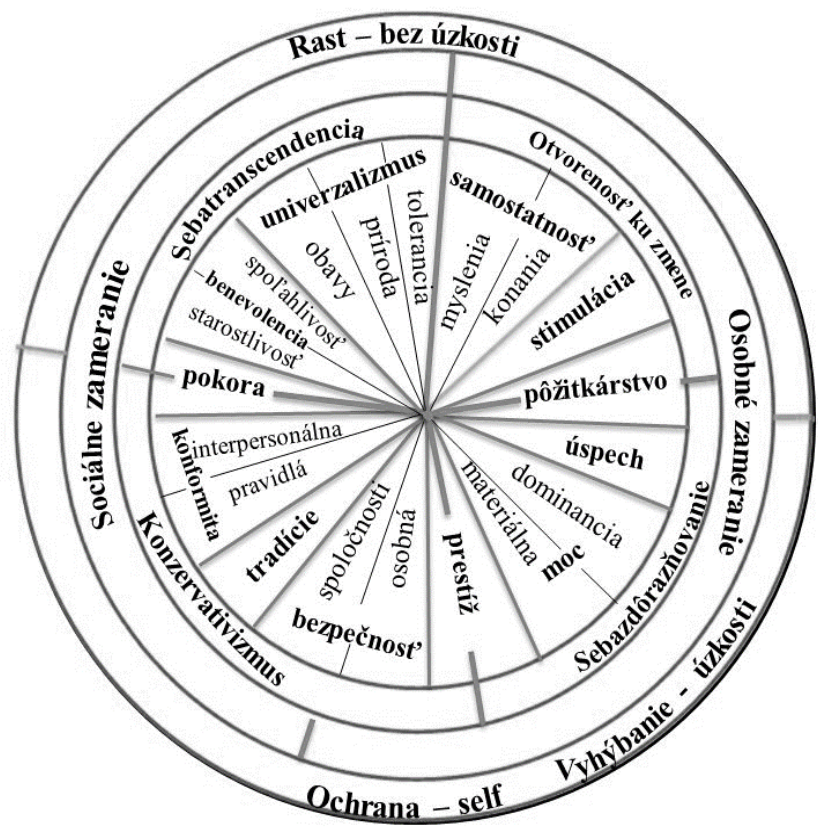

Obr.1: Cirkumplexný model vzt'ahov medzi hodnotovými motivačnými preferenciami (Schwartz, 2012)

\subsection{Hodnotová preferencia v súvislosti so sebahodnotením}

Lönnqvist a kol. (2009) sa vo svojom výskume zaoberali vzt'ahmi Schwartových desiatich základných typov hodnôt a sebahodnotenia jednotlivcov. Vzt’ah medzi sebahodnotením a hodnotami sledovali u stredoškolských študentov a dospelých účastníkov z piatich rozdielnych krajín. Zistil sa pozitívny vzt'ah medzi sebahodnotením a hodnotami sebaurčenie, stimulácia a úspech. Naopak negatívny vzt’ah so sebahodnotením zistili pri hodnotách univerzalizmus a benevolencia. Pri ostatných hodnotových typoch nezistili žiadne štatisticky významné vzt’ahy.

Deniz, Dilmaç a Hamarta (2016) taktiež skúmali vplyv hodnotových typov na sebahodnotenie. Výsledky výskumu naznačili, že preferencia jednotlivých typov hodnôt predikuje úroveň sebahodnotenia a mieru sociálnej podpory. Zistili, že hodnoty, úspech, moc a bezpečie sú významným prediktorom miery sebahodnotenia jednotlivcov. Na základe výsledkov svojho d'alšieho výskumu dodávajú, že hodnotu univerzalizmus môžeme považovat' za najvýznamnejší prediktor úrovne sebahodnotenia. Výsledky výskumu Feathera (1998) zas ukazujú, že globálne sebahodnotenie pozitívne koreluje s hodnotami týkajúcimi sa úspechu, spôsobilosti, vyspelosti a sebaurčenia.

Naše predpoklady vychádzajú zo zmienených empirických poznatkov. Na základe princípu komplementarity v cirkumplexnej štruktúre skúmaných hodnôt (Obr.1) predpokladáme pozitívne vzt'ahy so sebahodnotením $\mathrm{v}$ kvadrantoch Sebazdôrazňovania, Otvorenosti ku zmene a Sebatranscendencie a negatívne vzt’ahy v prípade kvadrantu Konzervativizmus. Budeme zist'ovat' 
vzt’ah medzi sebahodnotením a preferenciou hodnôt, a tiež rozdiel $\mathrm{v}$ miere preferencie jednotlivých hodnôt medzi študentmi s nižšou a vyššou úrovňou sebahodnotenia, pričom budeme analogicky predpokladat', že mladí l'udia s vyššou úrovňou sebahodnotenia budú preferovat' vo vyššej miere hodnoty Sebazdôrazňovania, Otvorenosti ku zmene a Sebatranscendencie. V prípade adolescentov s nižším sebahodnotením očakávame vyššiu preferenciu hodnôt Konzervativizmu.

\section{METÓDY}

\subsection{Výskumný súbor}

Výskumný súbor tvorili študenti štvrtého a piateho ročníka strednej odbornej školy agymnázia, pričom išlo o príležitostný výber. Štúdie sa zúčastnilo 108 respondentov (64 žien a 44 mužov) vo veku od 15 do 20 rokov. Respondenti sa teda nachádzali vobdobí neskoršej adolescencie (Vágnerová, 2005). Predpokladáme, že práve vtedy už by mohla byt' hodnotová štruktúra respondentov a ich sebahodnotenie viac stabilizované.

\subsection{Meracie nástroje}

Dotazník Portrait Value Questionnaire (PVQ - RR, Schwartz, 2012) je jeden z najpopulárnejších nástrojov na meranie hodnotových typov. Pôvodnú verziu dotazníka Schwartz revidoval a rozšíril. Dotazník sa skladá z 57 položiek a meria 19 individuálnych hodnôt (Obr. 1). Každá položka predstavuje verbálny opis určitého človeka, jeho ciele, priania, ašpirácie, ktoré implicitne smerujú k významu určitej hodnoty. Úlohou respondenta je určit' na 6 - bodovej Likertovej škále ako vel'mi sa na nich táto osoba podobá (Schwartz, 2012).

Rosenbergova škála sebahodnotenia (Rosenberg Self-Esteem scale; Rosenberg, 1965) je v súčasnosti najpoužívanejšia škála na meranie globálneho sebahodnotenia (globálne sebahodnotenie vyjadruje pozitívny alebo negatívny postoj k sebe samému ako celku). Pôvodná výskumná vzorka, pre ktorú bol dotazník vytvorený, pozostávala z cca. 5000 študentov stredných škôl z 10 náhodne vybratých škôl v New Yorku. Dotazník pozostáva z 10 položiek, a úlohou respondenta bolo vyjadrit' súhlas alebo nesúhlas $\mathrm{k}$ danému výroku na 4 - bodovej Likertovej škále. Dotazník má tzv. „cut off“ skóre, to znamená, že dokáže rozlíšit' respondentov s nižšou a vyššou úrovňou sebahodnotenia, čo nám umožnilo porovnávat’ dve skupiny respondentov.

\subsection{Metódy analýzy dát}

Dáta sme spracovali štatistickým programom IBM SPSS Statistics 21. Na overenie našich hypotéz sme zvolili bivariačnú vzt'ahovú analýzu. Vzhl'adom na normálny tvar distribúcie hodnôt dát sme použili Pearsonov koeficient súčinovej korelácie. V d'alšej časti sme sa venovali porovnávaniu jednotlivcov s vyšším a nižším sebahodnotením a ich hodnotovej orientácii. Na zist'ovanie rozdielov sme použili Studentov $t$ - test pre dva nezávislé výbery, nakol'ko naše dáta v pozorovaných skupinách zodpovedali normálnemu rozoženiu. Na hodnotenie efektu rozdielu v porovnávaných skupinách uvádzame ukazovatel' vecnej významnosti - Cohenovo d. Pri vol'be štatistických testov a vyhodnocovaní výsledkov sme vychádzali z odporúčaní, ktoré uvádzajú Sollár a Ritomský (2002).

\section{VÝSLEDKY}

Výsledky uvádzame v nasledujúcich tabul'kách, ktoré popisujú vzt'ah jednotlivých typov hodnôt so sebahodnotením (Tab.1) a rozdiely v úrovni jednotlivých hodnôt medzi respondentmi s vyšším a nižším sebahodnotením (Tab. 2) . 
Tab 1 Vzt'ah jednotlivých hodnôt a sebahodnotenia adolescentov $(n=108)$

\begin{tabular}{lcc} 
& \multicolumn{2}{c}{ Sebahodnotenie } \\
\cline { 2 - 3 } \multicolumn{1}{c}{ Hodnoty } & $\mathrm{r}$ & $\mathrm{p}$ \\
\hline Sebaurčenie-myslenie & $\mathbf{0 , 2 6 4}$ & $\mathbf{0 , 0 0 6}$ \\
Sebaurčenie-správanie & 0,026 & 0,790 \\
Stimulácia & 0,015 & 0,876 \\
Hedonizmus & $\mathbf{- 0 , 2 1 0}$ & $\mathbf{0 , 0 2 9}$ \\
Úspech & $-0,036$ & 0,715 \\
Moc-dominancia & $\mathbf{0 , 2 2 5}$ & $\mathbf{0 , 0 1 9}$ \\
Moc-materiálna & $\mathbf{- 0 , 3 7 2}$ & $<\mathbf{0 , 0 0 1}$ \\
Prestíž & $-0,054$ & 0,580 \\
Bezpenost'-osobné & $-0,078$ & 0,425 \\
Bezpečnost'-spoločenská & $-0,023$ & 0,813 \\
Tradícia & 0,041 & 0,677 \\
Konformita - pravidlá & 0,089 & 0,362 \\
Konformita-interpersonálna & $\mathbf{- 0 , 2 2 4}$ & $\mathbf{0 , 0 2 0}$ \\
Pokora & $\mathbf{0 , 2 1 2}$ & $\mathbf{0 , 0 2 8}$ \\
Univerzalizmus - príroda & $\mathbf{0 , 2 2 3}$ & $\mathbf{0 , 0 2 0}$ \\
Univerzalizmus -záujem & $\mathbf{0 , 2 6 7}$ & $\mathbf{0 , 0 0 5}$ \\
Univerzalizmus -tolerancia & 0,125 & 0,198 \\
Benevolencia -starostlivost' & $\mathbf{- 0 , 2 2 1}$ & $\mathbf{0 , 0 2 1}$ \\
Benevolencia -spol'ahlivost' & $-0,079$ & 0,416 \\
\hline \multicolumn{1}{c}{ Legenda: $n$ - počet participantov, $r$ - Pearsonov korelačný koeficient, } \\
\multicolumn{1}{c}{$p$ - štatistická významnost' } & &
\end{tabular}

Analýza vzt'ahov hodnôt sebaurčenia a hodôt kvadrantu Otvorenost' ku zmene ukázala, že sa naše predpoklady potvrdili iba v prípade slabého pozitívneho vzt'ahu - hodnoty sebaurčenie-myslenie vo vzt'ahu k sebahodnoteniu $(r=0,264 ; \mathrm{p}=0,006)$. U hodnôt osobného zamerania sme významný negatívny vzt'ah so sebahodnotením zistili v prípade hedonizmu ( $\mathrm{r}=-0,210 ; \mathrm{p}=0,029)$ a hodnoty moc-materiálna $(r=-0,372 ; p<0,001)$. Slabý pozitívny vzt'ah sa potvrdil s hodnotou mocdominancia ( $\mathrm{r}=0,225 ; \mathrm{p}=0,019)$.

Naše očakávania negatívnych vzt’ahov sebahodnotenia s hodnotami kvadrantu Konzervativizmu sa potvrdili iba v prípade hodnoty konformita-interpersonálna, kde bol zistený slabý negatívny vzt'ah $(r=-0,224 ; p=0,020)$. Ostatné sledované hodnoty z kvadrantu Konzervativizmus neboli vo vzt'ahu k sebahodnoteniu štatisticky významné.

V prípade kvadrantu Sebatranscendencie sa naše predpoklady potvrdili, až na predpokladaný vzt’ah sebahodnotenia s hodnotou benevolencia-spol'ahlivost'. Významný vzt’ah sme v tomto prípade nezistili. V prípade vzt'ahu hodnoty benevolencia-starostlivost' a sebahodnotenia sme zistli negatívny slabý vzt’ah $(\mathrm{r}=-0,221 ; \mathrm{p}=0,021)$. Ostatné vzt'ahy boli tak, ako sme predpokladali, štatisticky významné a pozitívne. Tesnost' vzt'ahov bola slabá $(r=0,125-0,267 ; p<0,05)$. 
Tab2 Rozdiel v hodnotách adolescentov s vyšším a nižším sebahodnotením

\begin{tabular}{|c|c|c|c|c|c|c|c|c|}
\hline \multirow[t]{2}{*}{ Hodnoty } & \multicolumn{2}{|c|}{$\begin{array}{c}\text { Nižšie } \\
\text { sebahodnotenie } \\
(n=45)\end{array}$} & \multicolumn{2}{|c|}{$\begin{array}{l}\quad \text { Vyššie } \\
\text { sebahodnot } \\
\text { enie } \\
\quad(n=63)\end{array}$} & \multirow{2}{*}{$\mathbf{t}$} & \multirow{2}{*}{ df } & \multirow{2}{*}{$\mathbf{p}$} & \multirow{2}{*}{ d } \\
\hline & $\mathbf{M}_{1}$ & $\mathbf{S D}_{1}$ & $\mathbf{M}_{2}$ & $\mathbf{S D}_{2}$ & & & & \\
\hline Sebaurčenie-myslenie & $-0,09$ & 0,69 & ,38 & 0,76 & $-3,309$ & 106 & 0,001 & $\begin{array}{l}- \\
0,582\end{array}$ \\
\hline Sebaurčenie-správanie & 0,44 & 0,68 & 68 & 0,66 & $-1,837$ & 106 & 0,069 & $-0,194$ \\
\hline Stimulácia & $-0,07$ & 0,67 & 18 & 0,97 & $-1,563$ & 106 & 0,121 & $-0,152$ \\
\hline Hedonizmus & 0,64 & 0,91 & 46 & 0,96 & 0,993 & 106 & 0,322 & 0,192 \\
\hline Úspech & 0,24 & 0,61 & ,27 & 0,64 & $-0,224$ & 106 & 0,823 & $-0,043$ \\
\hline Moc-dominancia & $-1,72$ & 1,01 & $-1,14$ & 1,11 & $-2,733$ & 106 & 0,007 & $-0,388$ \\
\hline Moc-majetok & $-1,45$ & 0,89 & $-1,73$ & 1,19 & 1,405 & 105,6 & 0,163 & 0,195 \\
\hline Prestíž & 0,06 & 0,93 & 172 & 0,77 & $-0,669$ & 106 & 0,505 & $-0,129$ \\
\hline Bezpenost'-osobné & 0,17 & 0,49 &,- 05 & 0,84 & 1,731 & 102,8 & 0,086 & 0,198 \\
\hline Bezpečnost'-spoločenská & 0,32 & 0,74 & 12 & 0,73 & 1,268 & 106 & 0,208 & 0,194 \\
\hline Tradícia & $-0,12$ & 0,61 &,- 22 & 0,85 & 0,965 & 106 & 0,337 & 0,187 \\
\hline Konformita - pravidlá & $-0,94$ & 1,02 & $-1,17$ & 1,1 & 0,615 & 106 & 0,540 & 0,119 \\
\hline $\begin{array}{l}\text { Konformita- } \\
\text { interpersonálna }\end{array}$ & 0,14 & 0,91 &,- 26 & 0,98 & 1,836 & 106 & 0,069 & 0,194 \\
\hline Pokora & $-0,14$ & 1,02 &,- 13 & 0,83 & $-0,048$ & 106 & 0,962 & $-0,009$ \\
\hline Univerzalizmus - príroda & $-0,47$ & 0,92 &,- 42 & 1,1 & $-0,281$ & 106 & 0,780 & $-0,054$ \\
\hline Univerzalizmus -záujem & 0,57 & 0,62 & 0,73 & 0,69 & $-1,184$ & 106 & 0,239 & $-0,230$ \\
\hline Univerzalizmus -tolerancia & 0,33 & 0,61 & 0,32 & 0,83 & 0,095 & 106 & 0,925 & 0,018 \\
\hline Benevolencia -starostlivost' & 0,97 & 0,70 & 0,81 & 0,48 & 1,376 & 72,49 & 0,173 & 0,236 \\
\hline Benevolencia -spol'ahlivost' & 1,08 & 0,69 & 0,99 & 0,53 & 0,705 & 79,31 & 0,483 & 0,158 \\
\hline
\end{tabular}

Legenda: $n$ - počet probantov, $M$ - priemer, $S D$ - štandardná odchýlka, $t$-Studentov $t$ - test, df - stupne vol'nosti, $p$ - štatistická významnost'

V prípade sledovaných rozdielov medzi skupinou respondentov s nižšou a vyššou úrovňou sebahodnotenia sa naše predpoklady potvrdili iba pri dvoch z devätnástoch sledovaných hodnôt. A to v prípade rozdielu v hodnote $\mathrm{z}$ kvadrantu Otvorenost' ku zmene: sebaurčenie-myslenie. Tak, ako sme predpokladali adolescenti s vyšším sebahodnotením vykazujú vyššiu úroveň hodnoty sebaurčenie-myslenie $(M=0,38 ; \mathrm{SD}=0,76)$ než adolescenti s nižšou úrovňou sebahodnotenia $(\mathrm{M}=$ $-0,0 ; \mathrm{SD}=0,69)$. Miera efektu rozdielu je stredne silná $(\mathrm{d}=-0,582)$.

Druhým potvrdeným rozdielom je rozdiel medzi sledovanými skupinami v prípade hodnoty z kvadrantu Sebaurčenie, a to $v$ úrovni hodnoty moc-dominancia. Adolescenti s vyšším sebahodnotením vykazujú vyššiu úroveň hodnoty moc-dominancia $(M=-1,14, S D=1,11)$ než adolescenti, ktorí majú nižšie sebahodnotenie ( $M=-1,72, S D=1,01)$. Vecná významnost' rozdielu je v tomto prípade malá.

Iné rozdiely medzi respondentmi s vyšším a nižším sebahodnotením sme nepotvrdili a miera efektu rozdielov sa pohybuje v rozmedzí od zanedbatel'nej po malú $d=|0,018-236|$. 


\section{DISKUSIA}

Ciel'om štúdie bolo identifikovat' vzt'ahy medzi sebahodnotením a 19 hodnotami revidovanej Schwartzovej teórie základných l’udských hodnôt (Schwartz, 2012). Komparačná čast' našej štúdie sa venovala rozdielom medzi stredoškolskými študentmi s vyššou a nižšou úrovňou sebahodnotenia v rámci jednotlivých hodnôt. Výsledky diskutujeme v poradí, v akom ich uvádzame v Tabul'ke 1 a Tabul'ke 2 v kapitole Výsledky.

\subsection{Vzt'ah medzi hodnotami kvadrantu Otvorenosti ku zmene a sebahodnotením}

Hodnoty sebaurčenia sú podl'a Schwarta (2012) a Deniza, Dilmaça a Hamarta (2016) významné zdroje sebahodnotenia jednotlivca. Podl'a týchto autorov hodnoty sebaurčenia taktiež stimulujú vývoj sebahodnotenia. Štatisticky pozitívny významný vzt’ah so sebahodnotením sa potvrdil len pri hodnote sebaurčenie- myslenie. Sloboda vytvárania vlastných myšlienok by mohla byt' určitým ukazovatel'om miery sebahodnotenia, pričom sloboda konania, ako je definová hodnota sebaurčenie-konanie, takýmto ukazovtel'om byt' nemusí. Kognitívne procesy častokrát zahŕňajú aj skryté myšlienky, ktoré s konaním, ktoré je prejavované navonok nemusia korešpondovat', čo popisuje aj teória kognitívnej disonancie (Festinger, 1957). Sebahodnotenie sa môže prejavovat' navonok, avšak jeho základ predstavujú primárne vnútorné procesy - vzt’ah k sebe samému, pocit vlastnej hodnoty a hodnotenie samého seba (Brown, Dutton, \& Cook, 2001).

Hodnota sebaurčenie - konanie je bližšie umiestená k hodnote stimulácia (Obr. 1), pri ktorej sa v našom výskume taktiež neprejavil žiaden vzt’ah so sebahodnotením. Naše výsledky sú v súlade $\mathrm{s}$ výskumami Šramovej, Džupiny a Juráškovej (2013) a Yildiza Dilmaça a Deniza (2013), ktorým sa pri zist'ovaní vzt'ahu medzi sebahodnotením a hodnotami u adolescentov, neprejavil žiaden vzt'ah hodnoty stimulácie a sebahodnotenia.

Štatisticky významný, aj ked' slabý negatívny vzt'ah sme zistili medzi sebahodnotením a hodnotou hedonizmus. Podobný výsledok predkladajú Dziwota a kol. (2016), ktorých štúdia odhalila, že l'udia s nízkym sebahodnotením prirad'ujú väčší význam hodnotám ako je hedonizmus. L'udia s nízkym sebahodnotením častejšie prežívajú negatívne emócie, ako je sklamanie a pocity nešt’astia, ked'že sebahodnotenie obsahuje aj pocitovú zložku (Brown, Dutton, \& Cook, 2001). Takýto l'udia môžu tak väčší význam prikladat' hodnote hedonizmu, ktorá súvisí s potrebou prežívat' potešenie a pozitívne pocity (Schwartz, 2012).

\subsection{Vzt'ah medzi hodnotami kvadrantu Sebazdôrazňovania a sebahodnotením}

Vzt'ahu medzi sebahodnotením a hodnotou úspech sa venovalo vel'ké množstvo výskumov, avšak dosiahnuté výsledky sú variabilné a nekonzistentné (Bahrami \& Bahrami, 2015). V našom prípade sme nezaznamenali štatisticky významný vzt’ah s touto hodnotou.

Aj ked' sa pri oboch hodnotách moci prejavil signifikantný vzt’ah, pozitívny vzt’ah so sebahodnotením sa nám však potvrdil len pri hodnote moc - dominancia. K rovnakým výsledkom dospeli aj Wojciszke a Struzynska - Kujalowicz (2017), ktorých výskum taktiež preukázal pozitívnu koreláciu medzi sebahodnotením a hodnotou moc - dominancia a taktiež aj s inými súvisiacimi vlastnost'ami, ako je extraverzia a líderstvo. Autori dodávajú, že schopnost' mat' kontrolu nad ostatnými by sme len t'ažko hl'adali u l'udí s nízkym sebahodnotením, nakol'ko mat' moc nad inými l'ud'mi si vyžaduje vieru vo vlastné schopnosti. Woolfe (2018) tvrdí, že ak človek uprednostňuje hodnotu moc - majetok z dôvodu zvýšenia si vlastného sebahodnotenia, môže v živote robit' rozhodnutia, ktoré nie sú v súlade $\mathrm{s}$ jeho vášňami, snami a ciel'mi. Takíto l'udia často zotrvajú $\mathrm{v}$ kariére, pretože im poskytuje materiálne zabezpečenie, aj napriek tomu, že svoju prácu považujú za nudnú a neinšpirujúcu. Moc nad majetkom alebo inými zdrojmi bohatstva ešte nemusí nezaručovat' vyššiu úroveň sebahodnotenia. V prípade hodnoty - prestíž sa viacerí autori zmieňujú 
o skutočnosti, že medzi sebahodnotením a hodnotou prestíž existuje súvislost' (Dziwota a kol., 2016), naše výsledky vzt'ah nepotvrdili. Ak by sme skúmali však inú zložku sebahodnotenia napr. sebahodnotenie súvisiace s pocitom vlastnej hodnoty (Brown, Dutton, \& Cook, 2001), možno by sme súvislost' zistili.

\subsection{Vzt'ah medzi hodnotami kvadrantu Konzervativizmu a sebahodnotením}

Predpokladali sme významný negatívny vzt’ah medzi sebahodnotením a hodnotami bezpečie osobné a bezpečie - spoločenské. Štatisticky významný vzt’ah sme však nepotvrdili. Naše výsledky sú v súlade s výsledkami Shashavari (2012) a Yildiz, Dilmaç, \& Deniz (2013). Taktiež sme nepotvrdili významný vzt’ah medzi sebahodnotením a hodnotou tradícia. Výsledky výskumov od Yildiza, Dilmaça a Deniza (2013) a Beckera a kol. (2014) taktiež hovoria o vel'mi malom alebo žiadnom vzt’ahu medzi hodnotou tradícia a sebahodnotením jednotlivca.

Predpokladali sme štatisticky významný negatívny vzt’ah medzi sebahodnotením a hodnotami konformita - pravidlá a konformita - interpersonálna. Štatisticky významný negatívny vzt’ah sa nám však potvrdil len pri hodnote konformita - interpersonálna. K rovnakým výsledkom dospeli aj Dziwota a kol. (2016). Práve hodnota konformita - interpersonálna súvisí s túžbou l'udí získat' alebo udržat' si miesto v sociálnej skupine. Interpersonálna konformita je práve zvlášt' dôležitá u l'udí s nízkym sebahodnotením, nakol'ko im pomáha získat' uznanie v sociálnej skupine a ako keby môže „zastierat"“ mieru nízkeho sebahodnotenia.

\subsection{Vzt'ah medzi hodnotami kvadrantu Sebatranscendencie a sebahodnotením}

Naše zistenia, že pokora pozitívne súvisí so sebahodnotením potvrdzujú aj výskumy Davisa a kol., (2012) a Owensa, Johnsona a Mithella (2013), ktorí nehovoria len o pozitívnom vzt'ahu pokory so sebahodnotením, ale taktiež zistili, že pokora je spojená so schopnost’ou vytvárat' si silnejšie sociálne väzby a rozvíjat' vlastné kvality.

Deniz, Dilmaç a Hamarta (2016) konštatujú, že najdôležitejšie hodnoty, ktoré predpovedajú sebahodnotenie jednotlivca sú hodnoty univerzalizmu. Štatisticky významný pozitívny vzt'ah so sebahodnotením sa potvrdil pri hodnotách univerzalizmus - príroda, univerzalizmus - záujem. Deniz, Dilmaç a Hamarta (2016) d’alej dodávajú, že čím viac si človek uvedomuje svoje univerzálne hodnoty, tým viac sa úroveň jeho sebahodnotenia zvyšuje.

V prípade hodnoty benevolencia - starostlivost' sa prejavil štatisticky významný negatívny vzt'ah so sebahodnotením, čo nebolo v našom prípade očakávané. Môžeme sa zamysliet' nad podobným vysvetlením ako v prípade hodnoty konformita - interpersonálna, kde sme taktirž zistili negatívny vzt'ah so sebahodnotením. A teda, že záujem o druhých blaho môže byt' zásterkou nižšej miery sebavedomia, príp. potreby overovania si vlastnej hodnoty prostredníctvom významných druhých, čo je v adolescentnom veku bežné (Langmeier \& Krejčŕŕrová, 2006).

\subsection{Rozdiely vhodnotovej preferencii adolescentov s nižším a vyšším sebahodnotením}

Štatisticky významné rozdiely medzi skupinami s nižším a vyšším sebahodnotením sme preukázali len pri hodnotách z kvadrantov, ktoré prislúchajú osobnému zameraniu (Obr. 1), a to pri hodnotách sebaurčenie - myslenie a moc - dominancia. Hodnotu sebaurčenie - myslenie preferovali jednotlivci s vyšším sebahodnotením. Zaznamenali sme stredný efekt rozdielu (Tabul'ka 2). Podl'a Schwartza (2012) sa hodnoty sebaurčenia výrazne zameriavajú na sebahodnotenie človeka a stimulujú jeho vývoj. Hodnotu moc - dominancia preferovali jednotlivci s vyšším sebahodnotením, vecná významnost’ bola však malá.

V oboch prípadoch sme zaznemnali so sebahodnotením pozitívne, aj ked' slabé vzt'ahy (Tabul'ka 1), čo len potvrdzuje dosiahnuté výskledky v rámci komparačnej časti štúdie. Vieme tak priblížit', ktoré z hodnôt, ktoré sa vo vzt’ahu k sebahodnoteniu ukázali ako slabé potvrdili svoju dôležitost’ aj 
v komparačnej časti štúdie. Ostatné hodnoty sa v skupinách s vyššou a nižšou úrovňou hodnotenia významne nelíšili, vecná významnost' sa pohybovala na zanedbatel'nej alebo nízkej úrovni.

\subsection{Limity štúdie a odporúčania pre d’alší výskum}

Za jeden z limitov výskumu považujeme aj to, že náš výskumný súbor pozostával len zo študentov dvoch stredných škôl. Preto neodporúčame výsledky generalizovat'. Taktiež si uvedomujeme, že náš výskumný súbor mohli tvorit’ aj jednotlivci, ktorí odpovedali na otázky v dotazníku bez zamyslenia alebo sa chceli ukázat' v lepšom svetle, čo mohlo skreslit' naše zistenia.

Námetom pre d’alší výskum by mohlo byt' aj použitie inej metódy na meranie úrovne sebahodnotenia napr. Coopermisthov dotazník (Coopersmith, 1967), ktorý skúma rôzne typy sebahodnotenia, a tak poznatky rozšírit', nakol'ko doterajšie výskumy poukazujú na rozporuplné zistenia a korelačná čast' našej štúdie poukázala iba na slabé vzt'ahy medzi globálnym sebahodnotením a hodnotami, ktoré by pri špecifických typoch sebahodnotenia mohli byt' iné.

\section{ZÁVER}

Výsledky nášho výskumu poukázali na štatisticky slabé významné pozitívne vzt'ahy medzi sebahodnotením a hodnotami sebaurčenie - myslenie, moc - dominancia, pokora, univerzalizmus - príroda a univerzalizmus - záujem. Pri hodnotách hedonizmus, konformita - interpersonálna, moc - majetok a benevolencia - starostlivost' sme zistili štatisticky významné slabé negatívne vzt'ahy so sebahodnotením. Rozdiely medzi študentmi s nižšou a vyššou úrovňou sebahonotenia sa zistili vpreferovaných hodnotách sebaurčenie-myslenie a moc-dominancia, ktoré sú charakteristické svojim osobným zameraním (Obr. 1). Ked’že zmienené hodnoty prejavili pôsobenie vkorelačnej aj komparačnej časti analýz, mohli by bližšie objasňovat' teóriu sebahodnotenia. Vzt'ahy, ktoré sme zistili sú však slabé, preto je potrebné d’alej skúmat' premenné, ktoré by lepšie vysvetl'ovali rôznu úroveň sebahodnotenia a preferovania hodnôt študentmi stredných škôl.

\section{LITERATÚRA}

Bahrami, D., \& Bahrami, M. A. (2015). The relationship of self-esteem and achievement goals with academic performance. African Journal of Basic \& Applied Sciences, 7(1), 65-72.

Becker, M., Vignoles, V. L., Owe, E., Easterbrook, M. J., Brown, R., Smith, P. B., ... \& Aldhafri, S. (2014). Cultural bases for self-evaluation: Seeing oneself positively in different cultural contexts. Personality and Social Psychology Bulletin, 40(5), 657-675.

Brown, J. D., Dutton, K. A., \& Cook, K. E. (2001). From the top down: Self-esteem and selfevaluation. Cognition and emotion, 15(5), 615-631.

Çakar, F. S., \& Karatas, Z. (2017). Adolescents' Self-Esteem, School Anger and Life Satisfaction as Predictors of Their School Attachment. Egitim ve Bilim, 42(189).

Coopersmith, S. (1967). The Antecedents of Self Esteem, W. H. Freeman, San Francisco.

Davidov, E., Schmidt, P., \& Schwartz, S. H. (2008). Bringing values back in: The adequacy of the European Social Survey to measure values in 20 countries. Public opinion quarterly, 72(3), 420-445. Davis, D. E., Worthington Jr, E. L., Hook, J. N., Emmons, R. A., Hill, P. C., Bollinger, R. A., \& Van Tongeren, D. R. (2013). Humility and the development and repair of social bonds: Two longitudinal studies. Self and Identity, 12(1), 58-77.

Deniz, M., Dilmaç, B., \& Hamarta, E. (2016). Values as predictors of teacher trainees' self-esteem and perceived social support. Social Sciences and Education Research Review, 3(1), 63-76.

Dziwota, K., Dudek, A., Szpak, A., Ludwikowska, K., Kowalski, D., Drabarek, Ł., ... \& Olajossy, M. (2016). Value preferences in individuals with low and high self-esteem. Current Problems of Psychiatry, 17(2), 97-106. 
Feather, N. T. (1998). Attitudes toward high achievers, self-esteem, and value priorities for Australian, American, and Canadian students. Journal of Cross-Cultural Psychology, 29(6), 749-759. Festinger, L. (1957). A theory of cognitive dissonance (Vol. 2). Stanford university press.

Fontana, D. (2003). Psychologie ve školní praxi. 2. vyd. Praha. Portál, (s 138).

Kusý, P. (2017). Signifikantní druhí v živote dospievajúcich v detskom domove. In Kanovská Halamová, J. 2017. Komunitná psychológia na Slovensku (pp. 104 - 119). Bratislava: Univerzita Komenského v Bratislave.

James, W. (1890). 1950. The principles of psychology. Volume I.

Langmeier, J. K., \& Krejčířová, D.(2006) Vývojová psychologie. 2. vyd. Praha: Grada.

Lönnqvist, J. E., Verkasalo, M., Helkama, K., Andreyeva, G. M., Bezmenova, I., Rattazzi, A. M. M., ... \& Stetsenko, A. (2009). Self-esteem and values. European Journal of Social Psychology, 39(1), 40-51.

Minev, M., Petrova, B., Mineva, K., Petkova, M., \& Strebkova, R. (2018). Self-esteem in adolescents. Trakia Journal of Sciences, 16(2), 115.

Owens, B. P., Johnson, M. D., \& Mitchell, T. R. (2013). Expressed humility in organizations: Implications for performance, teams, and leadership. Organization Science, 24(5), 1517-1538.

Rosenberg, M. 1965. Society and the adolescent self-image. Princeton: Princeton University Press, 1965. 340 p. ISBN 9780691649443.

Shahsavari, F. P. (2012). Relationship between Hierarchy of Values and Self-esteem among Iranian Students. Journal of American Science, 8(12).

Schusterová, N. (2008). Konstrukt " hodnota" v psychologickom ponímaní. Československá psychologie, 52(3), 265.

Schwartz, S. H. (2012). An overview of the Schwartz theory of basic values. Online readings in Psychology and Culture, 2(1), 2307-0919.

Sollár, T., \& Ritomský, A. (2002). Aplikácia štatistiky v sociálnom výskume. Nitra : Univerzita Konštantína Filozofa. 2002. 155 s.

Šramová, B., Džupina, M., \& Jurášková, O. (2013). Impact of value structure on brand engagement depending on degree of self-esteem of adolescents. International Journal of Innovation and Applied Studies, 3(4), 931-940.

Vágnerová, M. (2005). Vývojová psychologie I.: dětství a dospívání. Karolinum.

Vágnerová, M. (2010). Psychologie osobnosti. Karolinum.

Wojciszke, B., \& Struzynska-Kujalowicz, A. (2007). Power influences self-esteem. Social Cognition, 25(4), 472-494.

Woolfe, S. 2018. How Money Affects Self - Esteem [online]. [citované 2019-3-15]. Dostupné na internete: $\quad$ https://www.healthyplace.com/blogs/buildingselfesteem/2018/9/how-moneyaffects-self-esteem.

Yildiz, M., Dilmaç, B., \& Deniz, M. E. (2013). Analysis of the relation between self-esteem and values held by candidate teachers. Illkögretim Online, 12(3), 740-748.

\section{SELF - ESTEEM AND VALUE PREFERENCES IN HIGH SCHOOL STUDENTS}

Abstract: The main aim of work was to describe values and self - esteem of high school students and their relations. The secondary aim was to verify found relations by comparative analysis. The research sample consisted of 108 students (64 girls and 44 boys) aged from 15 to 20 . We used the Schwartz PVQ - RR scale to measure the value types. Self - esteem was examined by Rosenberg self - esteem scale. Results of the research showed statistically significant weak positive relationship between self esteem and values of self - direction - thought, power - dominance, humility, 
universalism - nature and universalism - concern. We found statistically significant weak negative relationship between self - esteem and values of hedonism, conformity - interpersonal, power - resources and benevolence - caring. Differences between students with lower and higher levels of self-esteem were found in the preferred values of self-direction - thought and power-dominance, these values could closer to clarify the theory of self-esteem.

Key words: Self-esteem, Schwartz theory of values, secondary school students

\section{Grantová podpora:}

Príspevok vznikol ako súčast' riešenia grantového projektu UGA IX/1/2019 Faktory efektívneho rozhodovania študentov podl'a Teórie kognitívneho spracovania informácií v oblasti kariérového poradenstva. 